\title{
Limited host range in the idiobiont parasitoid Phymastichus coffea, a prospective biological control agent of the coffee pest Hypothenemus hampei in Hawaii
}

\author{
Fazila Yousuf $^{1,2}$. Peter A. Follett ${ }^{1} \cdot$ Conrad P. D. T. Gillett $^{2} \cdot$ David Honsberger $^{2} \cdot$ Lourdes Chamorro $^{3}$. \\ M. Tracy Johnson ${ }^{4} \cdot$ Marisol Giraldo-Jaramillo ${ }^{5} \cdot$ Pablo Benavides-Machado ${ }^{5} \cdot$ Mark G. Wright $^{2}$
}

Received: 2 August 2020 / Revised: 7 February 2021 / Accepted: 15 February 2021 / Published online: 9 March 2021

(C) This is a U.S. government work and not under copyright protection in the U.S.; foreign copyright protection may apply 2021

\begin{abstract}
Phymastichus coffea LaSalle (Hymenoptera:Eulophidae) is an adult endoparasitoid of the coffee berry borer, Hypothenemus hampei (Ferrari) (Coleoptera:Curculionidae:Scolytinae), which has been introduced in many coffee producing countries as a biological control agent. To determine the effectiveness of $P$. coffea against $H$. hampei and environmental safety for release in Hawaii, we investigated the host selection and parasitism response of adult females to 43 different species of Coleoptera, including 23 Scolytinae (six Hypothenemus species and 17 others), and four additional Curculionidae. Non-target testing included Hawaiian endemic, exotic and beneficial coleopteran species. Using a no-choice laboratory bioassay, we demonstrated that $P$. coffea was only able to parasitize the target host $H$. hampei and four other adventive species of Hypothenemus: H. obscurus, H. seriatus, H. birmanus and H. crudiae. Hypothenemus hampei had the highest parasitism rate and shortest parasitoid development time of the five parasitized Hypothenemus spp. Parasitism and parasitoid emergence decreased with decreasing phylogenetic relatedness of the Hypothenemus spp. to H. hampei, and the most distantly related species, H. eruditus, was not parasitized. These results suggest that the risk of harmful non-target impacts is low because there are no native species of Hypothenemus in Hawaii, and P. coffea could be safely introduced for classical biological control of $H$. hampei in Hawaii.
\end{abstract}

Keywords Coffee berry borer $\cdot$ Host specificity testing $\cdot$ Non-target $\cdot$ Biocontrol $\cdot$ Endoparasitoid $\cdot$ Scolytinae

Communicated by Antonio Biondi .

Peter A. Follett

peter.follett@usda.gov

1 U.S. Department of Agriculture-Agricultural Research Service (USDA-ARS), Daniel K. Inouye U.S. Pacific Basin Agricultural Research Center, 64 Nowelo Street, Hilo, HI 96720, USA

2 Entomology Section, Department of Plant and Environmental Protection Sciences, University of Hawaii At Manoa, 3050 Maile Way, Honolulu, HI 96822, USA

3 Systematic Entomology Laboratory, Agricultural Research Service, U.S. Department of Agriculture, c/o National Museum of Natural History, Smithsonian Institution, MRC-168, P.O. Box 37012, Washington, DC 20013-7012, USA

4 U.S. Forest Service, Institute of Pacific Islands Forestry, and Hawaii Volcanoes National Park Quarantine Facility, Volcano, HI, USA

5 Centro Nacional de Investigaciones de Café - Cenicafe, Manizales, Colombia

\section{Key message}

- Phymastichus coffea is an idiobiont adult parasitoid of the coffee pest Hypothenemus hampei.

- In host range testing, P. coffea parasitized only five Hypothenemus spp.

- The parasitism rate was highest and parasitoid development time was shortest in H. hampei.

- No Hawaiian native species was parasitized by the parasitoid.

- Phymasticus coffea can be introduced safely for biocontrol of coffee berry borer in Hawaii. 


\section{Introduction}

The coffee berry borer, Hypothenemus hampei (Ferrari) (Coleoptera:Curculionidae:Scolytinae), native to Central Africa, is the most damaging insect pest of coffee worldwide, inflicting economical losses of over US \$500 million dollars annually (Vega et al. 2015). In Hawaii, H. hampei was first recorded in Kona, Hawaii island, in 2010 (Burbano et al. 2011) and is now widespread throughout all the coffee-growing areas of Hawaii. Coffee is the third largest cash crop in the state of Hawaii, valued at more than $\$ 43$ million (USDA-NASS 2018). Hypothenemus hampei has had the effect of making coffee farming more intensive and less profitable, which is a major economic challenge to small-scale coffee production like that in Hawaii (Johnson et al. 2020). If left unmanaged, $H$. hampei can damage $>90 \%$ of the crop.

Hypothenemus hampei attacks coffee berries when the dry matter content of the endosperm, which increases with age, exceeds $20 \%$ (Jaramillo et al. 2005). After finding a suitable berry host, $H$. hampei bores into the coffee fruit through the central disk and excavates galleries where it lays eggs. The offspring develop inside the seeds and feed on the endosperm tissue of the berries (Damon 2000), reducing both coffee yield and quality. Hypothenemus hampei feeding damage can also cause premature fall of berries younger than 80 days (Decazy 1990). Hypothenemus hampei adults boring into the berry may remain in the 'A' position (Jaramillo et al. 2006) with the abdomen half exposed outside the berry potentially for weeks waiting for the dry matter content to reach $20 \%$ (Jaramillo et al. 2005).

Strategies to control $H$. hampei include mechanical, chemical and biological controls (Infante 2018). Sanitation and biological control (using parasitoids, predators and entomopathogenic microorganisms) are the most sustainable, environmentally friendly and widely used non-chemical control methods. The parasitoids, Cepahlonomia stephanoderis Betrem, C. hyalinipennis Ashmead and Prorops nasuta Waterston (Hymenoptera:Bethylidae), Heterospilus coffeicola Schneideknecht (Hymenoptera:Braconidae) and Phymastichus coffea LaSalle (Hymenoptera:Eulophidae), all of African origin, have been introduced in many coffee producing countries, particularly in Central and South America (Klein-Koch et al. 1988; Barrera et al. 1990; Baker 1999; Jaramillo et al. 2005; Portilla and Grodowitz 2018), but none have been released in Hawaii. In Hawaii, the primary methods for controlling $H$. hampei are sanitation (frequent harvests and removal of all left over coffee berries after harvest) and applications of the biopesticide Beauveria bassiana (Ascomicota:Hypocreales), an entomopathogenic fungus (Aristizábal et al. 2016). Two generalist predators, Leptophloeus sp. and Cathartus quadricollis (Coleoptera:Laemophloeidae and Silvanidae, respectively), occur naturally in Hawaii coffee and have been shown to feed on immature stages of $H$. hampei in overripe and dried berries (Follett et al. 2016; Brill et al. 2020), but are not very efficient in preventing damage in the first place.

Most of the studies on biological control of $H$. hampei have been conducted outside Hawaii, but in similar coffee production systems. In field-cage studies conducted in Mexico and Costa Rica, $P$. coffea proved to be the most promising biological control agent against $H$. hampei with parasitism rates as high as 95\% (Espinoza et al. 2009; Infante et al. 2013). To date, $P$. coffea has been released in 12 countries as a classical biological control agent (Bustillo et al. 1998; Damon 2000; Jaramillo et al. 2005; Vega et al. 2015). Phymastichus coffea is native to Africa and present in most coffee producing countries on that continent. It is a primary, gregarious, idiobiont endoparasitoid of adult $H$. hampei females with a high capacity for host discrimination (Feldhege 1992; Infante et al. 1994; López-Vaamonde and Moore 1998; Castillo et al. 2004). Two laboratory studies reported that in addition to $H$. hampei, $P$. coffea parasitizes other Hypothenemus spp. such as $H$. seriatus and $H$. obscurus (López-Vaamonde and Moore 1998), and H. eruditus Westwood and H. crudiae (Panzer) (Castillo et al. 2004). However, parasitism of closely related species in the field has not been reported (Escobar-Ramírez et al. 2019). Gravid $P$. coffea females start to search for their hosts immediately after emerging from the adult female host and parasitism occurs within the first hours after emergence (Infante et al. 1994). Phymasticus coffea has an extremely short life span as an adult; the longevity of males ranges from 8 to $48 \mathrm{~h}$ and females from 16 to 72 h (Vergara et al. 2001; Portilla and Grodowitz 2018). Phymastichus coffea generally lays two eggs (into the abdomen, thorax, or between the thorax and abdomen) in an $H$. hampei adult female at the time she is initiating fruit perforation, which causes paralysis and prevents further damage to the coffee berry. The parasitized H. hampei usually dies within 4-12 days after parasitism (Infante et al. 1994). The life cycle (egg to adult) of $P$. coffea varies from 30 to 47 days depending on the environmental conditions (temperature and humidity). Females are $\sim 1 \mathrm{~mm}$ long, whereas males are half that size (LaSalle 1990).

Earlier studies have shown the high host specificity of $P$. coffea and its ability to significantly reduce and regulate $H$. hampei populations (Gutierrez et al. 1998; López-Vaamonde and Moore 1998; Castillo et al. 2004; Rodríguez et al. 2017). Therefore, we decided to consider $P$. coffea as a biological control agent of $H$. hampei in Hawaii. A critical step was to determine its host specificity and assess possible risks to the Hawaii environment though impacts on endemic and other non-target species (Follett and Duan 1999; Messing and Wright 2006). Greatest non-target species impacts from 
introduced biological control agents are likely to occur on species closely related to the target pest species (Van Driesche and Murray 2004), but not always (Messing 2001), and thus, phylogenetically closely and distantly related species should be included in non-target screening efforts. This is an important element of biological control, particularly in Hawaii, where classical biological control may have had significant negative impacts on native species in the past (e.g., Howarth 1991; Henneman and Memmott 2001). While some studies have suggested that this is true (see references in Messing and Wright 2006), a number of carefully crafted field studies of population level impacts on non-target species have suggested that introduced parasitoids have had minimal, or sometimes moderate, impacts on endemic species (Johnson et al. 2005; Kaufman and Wright 2009). Where higher impacts have been detected, they are typically from accidentally introduced parasitoid species, and host insects in disturbed habitats are most susceptible to these impacts (Kaufman and Wright 2011). However, the potential for non-target impacts must be carefully considered, and outcomes of exposures of unintended hosts to prospective biological control agents can provide insights into host range patterns and determinants.

In this paper, we present new insights into the host specificity of $P$. coffea, a prospective biological control agent of H. hampei in Hawaii, by testing it against 43 different species of Coleoptera. Non-target testing included Hawaiian endemic, exotic and beneficial coleopteran species. There are currently no records of native Hawaiian Hypothenemus spp. except for an old record (1913) of H. ruficeps (Swezey 1954), which has never been collected or reported since and is possibly a synonym with the adventive species $H$. eruditus or $H$. crudiae (C. Gillett, unpublished). There are, however, many native species in another scolytine genus, Xyleborus (Samuelson 1981; Gillett et al. 2019), which may potentially be impacted by release of an exotic parasitoid against a scolytine pest such as $H$. hampei. We test the hypothesis that $P$. coffea is host specific and will not attack native Hawaiian Scolytinae species.

\section{Materials and methods}

\section{Parasitoid, Phymastichus coffea}

Phymastichus coffea used in this study were obtained from an established stock maintained at the National Coffee Research Center-Cenicafé, Manizales (Caldas) Colombia, which was started from $P$. coffea collected in Kenya and shipped to Colombia in 1996 and has been maintained in colony in large numbers since that time (Orozco-Hoyas and Aristizábal 1996). Phymastichus coffea has been mass reared by Cenicafé for field releases on multiple occasions and the colony receives frequent infusions of field-collected material. Phymastichus coffea was shipped from Cenicafé in its larval stage in parasitized H. hampei hosts under USDA APHIS PPQ, permit no. P526P-18-00,696 to a certified quarantine insect containment facility managed by the USDA Forest Service at Hawaii Volcanoes National Park, Volcano, Hawaii. Parasitized $H$. hampei were incubated in controlled climate chambers at $25^{\circ} \pm 1^{\circ} \mathrm{C}, 75 \pm 10 \%$ relative humidity and 8:16 h light:dark photocycle at the quarantine containment facility.

Emerged male and female parasitoid adults were collected using a manual aspirator into a clean glass container. Parasitoids were held for mating and oocyte maturation and provided with $50 \%$ (w/v) honey (raw organic) solution for $\sim 2 \mathrm{~h}$ before being used in the experiments (López-Vaamonde and Moore 1998). Infante et al. (1994) reported that $P$. cof$f e a$ does not go through a preoviposition period and exhibits facultative arrhenotokous-type parthenogenesis, where the female parasitizes its host before or after copulation, producing haploid males (Portilla and Grodowitz 2018). Feldhege (1992) reported a preoviposition period of between $5 \mathrm{~min}$ and $4 \mathrm{~h}$. The adult parasitoids are very short-lived: males $(\sim 8-48 \mathrm{~h})$ and females ( 16-72 h) (Vergara et al. 2001; Rojas et al. 2006; Espinoza et al. 2009; Portilla and Grodowitz 2018). The ability to parasitize hosts decreases with age, so it was important to use freshly emerged parasitoids $(<12 \mathrm{~h}$ old $)$ in all experiments.

\section{Coffee berry borer, Hypothenemus hampei}

Field-collected $H$. hampei were used in all no-choice host specificity experiments. Hypothenemus hampeiinfested coffee berries were collected from coffee trees (Coffea arabica) at OK Coffee Farm in Hilo, Hawaii (19.727583, - 155.111186, elevation $156 \mathrm{~m})$. These collections were transported in cold boxes to the USDA-ARS laboratory and placed in a custom-made extraction unit lined with tissue paper (Tech wipes 1709/7052, Horizon) to absorb condensation and prevent mold growth. Adult $H$. hampei were collected directly from the infested coffee berries by dissecting the berries or from the extraction unit using an aspirator. All the collected H. hampei were provided with artificial diet (modified from Brun et al. 1993) until use in the experiments.

\section{Collection of non-target coleopteran species}

The selection of non-target hosts was based on phylogenetic relatedness to the target host, sympatry of target and nontarget species, and size. Species commonly occurring in the coffee landscape and species in culture at USDA-ARS in Hilo, Hawaii, were also tested. There are 21 native and 38 non-native scolytine species in Hawaii (Samuelson 1981; 
Nishida 2002; Cognato and Rubinoff 2008). Because of the relatively large native scolytine fauna in Hawaii, and their remote or poorly studied habitats, only a subset of these species could be tested for their suitability as hosts to P. cof$f e a$. Exotic and native scolytine species were collected from coffee and macadamia farms and their surrounding habitats, and from native forests from different islands (Hawaii Island, Oahu, Maui, Molokai and Kauai) in Hawaii (Gillett et al. 2020a). Host specificity tests were conducted with a total of 43 species from seven different coleopteran families including Hawaiian endemic species (several Scolytinae in the genus Xyleborus and Nesotocus giffardi, a curculionid weevil), exotic pest species (e.g., the scolytines Hypothenemus obscurus [tropical nut borer] and Xylosandrus compactus [black twig borer], and the curculionids Sitophilus oryzae [rice weevil] and Cylas formicarius [sweetpotato weevil]), and beneficial species (e.g., a weed biocontrol agent Uroplata girardi from lantana, several coccinellids, and two flat bark beetle predators of H. hampei, Catharus quadricollis and Leptophloeus sp.) (Tables 1, 2, 3, 4). All beetles used in host specificity tests were collected live and later preserved in $75 \%$ alcohol or pinned for identification by taxonomists with expertise in the respective taxa. The body size of the collected species ranged from 1 to $7 \mathrm{~mm}$, but the majority of species were similar in size to $H$. hampei which is $1.5-2.0 \mathrm{~mm}$ in length. Beetles were collected using Lindgren funnels or bucket or Broca traps baited with denatured ethanol only or ethanol + methanol + ethylene glycol lures or collected directly from infested plant material (fruits, pods, stems, bark and seeds) or reared from infested wood in the laboratory (Gillett et al. 2020b). All non-target testing was conducted at the USDA Forest Service quarantine containment facility at Hawaii Volcanoes National Park, Volcano, Hawaii.
Table 1 Development time and sex ratio of Phymasticus coffea in no-choice in vitro non-target host selection screening of Hypothenemus species, including $H$. hampei as a control species

\begin{tabular}{lllll}
\hline Species & Insect status & $\begin{array}{l}\text { Total beetles } \\
\text { exposed }\end{array}$ & $\begin{array}{l}\text { Development time } \\
\text { (days } \pm \text { SE) }\end{array}$ & $\begin{array}{l}\text { Sex ratio (mean } \\
\% \text { females } \pm \text { SE) }\end{array}$ \\
\hline Hypothenemus hampei (control) & Exotic/pest & 170 & $32.2 \pm 0.5$ & $50.8 \pm 0.4$ \\
Hypotheneтus obscurus & Exotic/pest & 80 & $35.0 \pm 0.9$ & $54.8 \pm 1.6^{*}$ \\
Hypotheneтus seriatus & Exotic & 60 & $38.0 \pm 1.0$ & $51.1 \pm 1.1$ \\
Hypotheneтus birmanus & Exotic & 40 & $37.0 \pm 1.0$ & $57.7 \pm 3.8^{*}$ \\
Hypothenemus crudiae & Exotic & 30 & $41.0 \pm 0.0^{*}$ & 50.0 \\
Hypothenemus eruditus & Exotic & 80 & - & - \\
\hline
\end{tabular}

*significantly different from Hypothenemus hampei (control), $p<0.05$

Table 2 Parasitism and parasitoid emergence rates in no-choice in vitro non-target host acceptance screening of Phymastichus coffea exposed to various Scolytinae (Hawaii native and non-native) species

\begin{tabular}{|c|c|c|c|c|c|}
\hline Family & Species & Insect status & $\begin{array}{l}\text { Total beetles } \\
\text { exposed }\end{array}$ & $\begin{array}{l}\text { Parasitism }(\%) \\
(\text { Mean } \pm \text { SE) }\end{array}$ & $\begin{array}{l}\text { Parasitoid } \\
\text { emergence }(\%) \\
(\text { Mean } \pm \text { SE) }\end{array}$ \\
\hline \multirow[t]{17}{*}{ Curculionidae:Scolytinae } & Xylosandrus compactus & Exotic/pest & 80 & 0 & 0 \\
\hline & Xylosandrus crassiusculus & Exotic & 80 & 0 & 0 \\
\hline & Xyleborinus saxeseni & Exotic & 80 & 0 & 0 \\
\hline & Xyleborinus andrewesi & Exotic & 60 & 0 & 0 \\
\hline & Xyleborus ferrugineus & Exotic & 60 & 0 & 0 \\
\hline & Euwallacea fornicatus & Exotic & 60 & 0 & 0 \\
\hline & Euwallacea interjectus & Exotic & 60 & 0 & 0 \\
\hline & Hypochryphalus sp. & Exotic & 60 & 0 & 0 \\
\hline & Chryphalus sp. & Exotic & 80 & 0 & 0 \\
\hline & Ptilopodius pacificus & Exotic & 80 & 0 & 0 \\
\hline & Xyleborus molokaiensis & Native & 30 & 0 & 0 \\
\hline & Xyleborus mauiensis & Native & 15 & 0 & 0 \\
\hline & Xyleborus simillimus & Native & 18 & 0 & 0 \\
\hline & Xyleborus hawaiiensis & Native & 9 & 0 & 0 \\
\hline & Xyleborus lanaiensis & Native & 19 & 0 & 0 \\
\hline & Xyleborus obliquus & Native & 3 & 0 & 0 \\
\hline & Xyleborus kauaiensis & Native & 35 & 0 & 0 \\
\hline
\end{tabular}


Table 3 Parasitism and parasitoid emergence rates in no-choice in vitro non-target host acceptance screening of Phymastichus coffea on beneficial Coleoptera species

\begin{tabular}{llllll}
\hline Family & Species & Insect status & $\begin{array}{l}\text { Total } \\
\text { beetles } \\
\text { exposed }\end{array}$ & $\begin{array}{l}\text { Parasit- } \\
\text { ism (\%) }\end{array}$ & $\begin{array}{l}\text { Parasitoid } \\
\text { emergence } \\
(\%)\end{array}$ \\
\hline Chrysomelidae:Cassidinae & Uroplata girardi & Exotic & 60 & 0 & 0 \\
Coccinellidae & Scymnodes lividigaster & Exotic & 40 & 0 & 0 \\
Coccinellidae & Rhyzobius forestieri & Exotic & 60 & 0 & 0 \\
Coccinellidae & Halmus chalybeus & Exotic & 40 & 0 & 0 \\
Laemophloeidae & Leptophloeus sp. & Unknown & 60 & 0 & 0 \\
Silvanidae & Cathartus quadricollis & Exotic & 80 & 0 & 0 \\
\hline
\end{tabular}

Table 4 Parasitism and parasitoid emergence rates in no-choice in vitro non-target host acceptance screening of Phymastichus coffea on Hawaiian native and introduced coleopteran species from families and subfamilies other than Curculionidae:Scolytinae

\begin{tabular}{|c|c|c|c|c|c|}
\hline Family & Species & Insect status & $\begin{array}{l}\text { Total beetles } \\
\text { exposed }\end{array}$ & $\begin{array}{l}\text { Parasitism } \\
(\%)\end{array}$ & $\begin{array}{l}\text { Parasitoid } \\
\text { emergence } \\
(\%)\end{array}$ \\
\hline Anthribidae & Araecerus simulatus or A. levipennis & Unknown & 6 & 0 & 0 \\
\hline Anthribidae & Araecerus sp. near varians & Unknown & 15 & 0 & 0 \\
\hline Brentidae:Brentinae & Cylas formicarius & Exotic/Pest & 80 & 0 & 0 \\
\hline Chrysomelidae:Bruchinae & Acanthoscelides macrophthalmus & Unknown & 10 & 0 & 0 \\
\hline Curculionidae:Cossoninae & Phloeophagosoma tenuis & Unknown & 8 & 0 & 0 \\
\hline Curculionidae:Cossoninae & Nesotocus giffardi & Native & 12 & 0 & 0 \\
\hline Curculionidae:Curculioninae & Sigastus sp. & Exotic/Pest & 6 & 0 & 0 \\
\hline Curculionidae:Platypodinae & Crossotarsus externedentatus & Exotic & 60 & 0 & 0 \\
\hline Dryophthoridae:Dryophthorinae & Sitophilus oryzae & Exotic/Pest & 60 & 0 & 0 \\
\hline Dryophthoridae:Dryophthorinae & Sitophilus linearis & Exotic & 40 & 0 & 0 \\
\hline Nitidulidae:Carpophilinae & Carpophilus dimidiatus & Exotic & 10 & 0 & 0 \\
\hline Nitidulidae:Carpophilinae & Carpophilus zeaphilus & Exotic & 60 & 0 & 0 \\
\hline Tenebrionidae & Tribolium castaneum & Exotic/Pest & 21 & 0 & 0 \\
\hline Tenebrionidae & Hypophloeus maehleri & Exotic & 60 & 0 & 0 \\
\hline
\end{tabular}

\section{No-choice tests}

In this study, we used no-choice tests because these would reflect physiological host range and the potential for parasitism in the field more accurately than choice tests (Van Driesche and Murray 2004). Choice tests that include the target host may mask the acceptability of lower ranked hosts, thereby producing false negative results (Withers and Mansfield 2005). Twenty individuals of each test species were placed in a sterilized glass Petri dish $(80 \mathrm{~mm}$ in diameter) lined with filter paper and immediately afterward four $P$. coffea females ( $<12 \mathrm{~h}$ old) that had not been exposed to adult hosts prior to the experiments were introduced. Therefore, when ample hosts were available, each replicate consisted of 20 hosts and four parasitoids for a 5:1 host-parasitoid ratio. However, due to difficulties in finding certain species live in adequate numbers, e.g., native scolytine bark beetles, and difficulties synchronizing parasitoid emergence with field collection or emergence from wood of live beetles, the host-parasitoid ratio and numbers of replicates were adjusted as needed. For example, if only 10 non-target beetles were available for screening, then two replicates each with 5 beetles and 1 parasitoid (maintaining the 5:1 host-parasitoid ratio) were performed. In all non-target host screening tests, H. hampei was included as a positive control to confirm parasitoid viability. The host-parasitoid ratio of the $H$. hampei controls was adjusted to match the non-target species in the test, whether it was $5: 1$ or otherwise. The generalized response of the parasitoids toward target and non-target hosts was also determined for a subset of parasitoids by visual observation and video recording of parasitoid behavior, e.g., any contact with the host by landing on the host or antennation, and/or walking on the host. Host acceptance was noted when the parasitoid adopted a characteristic oviposition position on top the elytra of the host (Lopez-Vaamonde and Moore 1998).

After $P$. coffea exposure, H. hampei and all other nontarget species were incubated at $25 \pm 1{ }^{\circ} \mathrm{C}, 75 \pm 10 \% \mathrm{RH}$ and 24:0 (L-D) photoperiod for $72 \mathrm{~h}$. After $72 \mathrm{~h}$, parasitoids and filter paper linings were removed and the beetles were 
provided with a small cube $(2 \times 2 \times 2 \mathrm{~cm})$ of general beetle $\operatorname{diet}(\mathrm{FY}$, unpublished). The beetles were again incubated at the same environmental conditions, but now at 0:24 (L-D). After 10 days, all the remaining diet and frass was removed (without disturbing the parasitized beetles) to avoid fungal contamination. Parasitized beetles typically become paralyzed and eventually die within 4-12 days after parasitoid oviposition. Beetles were held for a total of 5-6 weeks for parasitoid emergence. Beginning after 25-day incubation, $H$. hampei mummies were inspected daily for adult wasp emergence. Parasitism was assessed based on observation of emergence of parasitoid progeny ( $\mathrm{F} 1$ adult wasps) from the parasitized beetle, by inspection for exit holes on cadavers or by dissection. Beetles with no exit holes were dissected (by separating the thorax from the abdomen) under a stereomicroscope using fine forceps and entomological pins at 20-100X magnification for evidence of parasitism, i.e., presence of $P$. coffea immature life stages (eggs, larvae or pupae), or unemerged adults. The number of unemerged life stages was recorded for each dissected beetle. After 5-6 weeks of incubation, dead beetle specimens sometimes became very dry and searching for the presence of eggs and early instar larvae was difficult. In such cases, beetles were dissected and examined under a compound microscope at 200X to seek unemerged $P$. coffea. The sex of emerged adult $P$. coffea offspring was determined by examination using a stereomicroscope. In most cases, two parasitoids (one male and one female) emerged per beetle host. To confirm this, the sum of the emerged male and female parasitoids in each replicate was divided by two and compared to the number of parasitized hosts with exit holes. The sex of unemerged parasitoids was not determined. For data on parasitism, life stages, sex ratio and development time, averages were calculated for each replicate (per Petri dish) for each species and used in statistical analysis. Grand means of all the replicates for each of the five Hypothenemus species are presented in figures and tables.

\section{Statistical analysis}

Parasitism rate was calculated by dividing the number of parasitized hosts by the total number of hosts exposed to the parasitoids. Parasitism included both emerged and unemerged wasps. Emergence rate was calculated by dividing the number of beetles with exit holes by the total number of parasitized hosts (emerged plus unemerged wasps). The sex ratio of the parasitoid progeny was calculated by dividing the number of emerged female parasitoids $(\mathrm{F})$ by the total number of emerged male $(\mathrm{M})$ and female $(\mathrm{F})$ parasitoids $[\mathrm{F} /$ $(\mathrm{F}+\mathrm{M}) \times 100]$. The Shapiro-Wilk test (Shapiro and Wilk 1965; Razali and Wah 2011), numerical approaches (skewness and kurtosis indices) and the normal Q-Q plot-based graphical method were used to check the distribution of the data and showed that the data were not normally distributed. Generalized linear models (GLM) were therefore used to analyze the data, with appropriate distribution function links. Parasitism and emergence rates of the parasitoids, and the percentage of different life stages (larvae, pupae and adults) in parasitized beetles with unemerged parasitoids were analyzed using GLM with a binary logistic function and sex ratio with a gamma log link function. Developmental time of the F1 offspring (egg to adult) was analyzed using GLM with a negative binomial log link function because data were overdispersed (i.e., variance $>$ mean). Wald Chisquared approximations are reported. All analyses were performed using IBM SPSS statistics software.

\section{Results}

Out of 43 total coleopteran species tested, including 23 scolytines, $P$. coffea oviposited and completed developed only in the target Hypothenemus hampei and four other species of Hypothenemus: H. obscurus, H. seriatus, $H$. birmanus and $H$. crudiae. Mean percentages of parasitism and emergence for the Hypothenemus spp. tested are shown in Fig. 1. Parasitism $\left(\chi^{2}=65.13, \mathrm{df}=4, p=0.0001\right)$ and emergence $\left(\chi^{2}=23.20, \mathrm{df}=4, p=0.0001\right)$ were significantly higher in $H$. hampei than all other Hypothenemus

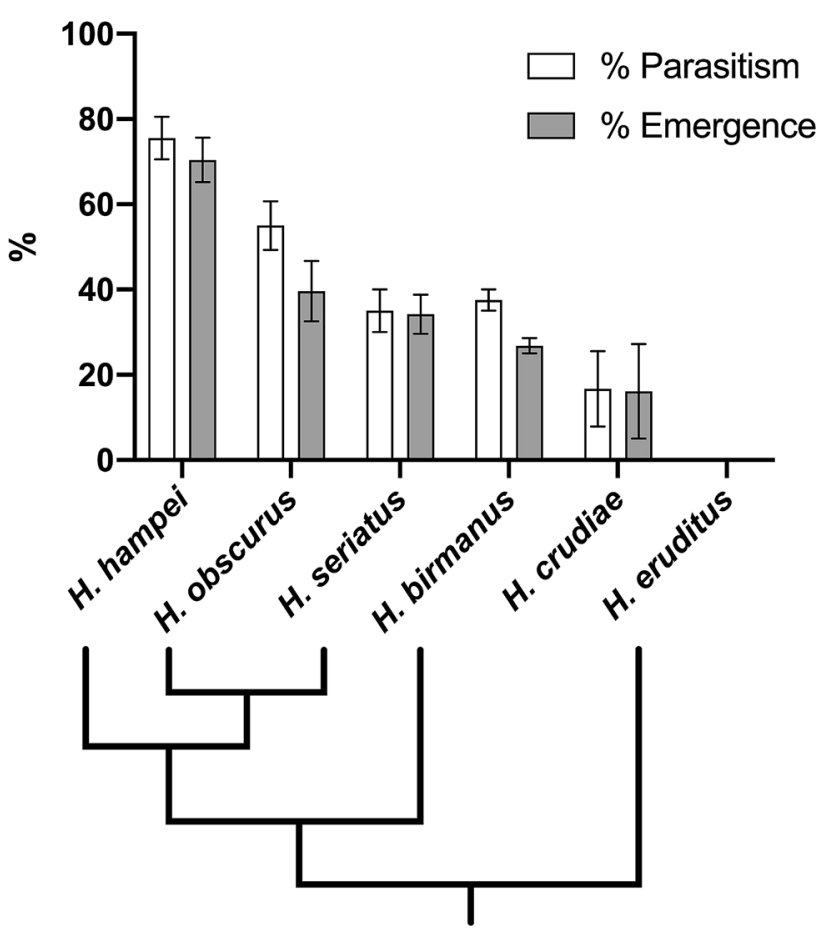

Fig. 1 Percentage parasitism and emergence (mean \pm SE) of adult Phymastichus coffea parasitoids from Hypothenemus spp. The phylogeny below the graph for the species included in the study (except H. crudiae) was inferred from Johnson et al. (2018) 
species. Hypothenemus hampei had the highest percentage emergence of $P$. coffea at $70.4 \%$, whereas $H$. crudiae had the lowest at $16.7 \%$ (Fig. 1). In H. crudiae, out of five parasitized hosts only one had emergence. Although $P$. coffea only parasitized Hypothenemus spp., it did inspect three other non-target scolytine hosts, Hypothenemus eruditus, Xyleborus kauaiensis and Xyleborus ferrugineus, but left hosts without initiating oviposition (i.e., no parasitism found). The phylogenetic relationship of five Hypothenemus species included in our tests, extracted from Johnson et al. (2018), is also shown in Fig. 1; H. crudiae is not included in the phylogeny because it was not included in Johnson et al (2018). Both parasitism and emergence in our tests decreased across Hypothenemus species with decreasing phylogenetic relatedness to H. hampei. Hypothenemus eruditus, the most distantly related species from H. hampei according to Johnson et al. (2018), was not parasitized (Fig. 1).

Parasitoid development time among the three different Hypothenemus spp. did not differ significantly compared with $H$. hampei $\left(\chi^{2}=0.17, \mathrm{df}=4, p=0.997\right)$, but did differ with $H$. crudiae (Table 1). The mean development time of $P$. coffea from oviposition to adult emergence was shortest in $H$. hampei $(32.2 \pm 0.5$ days, mean $\pm \mathrm{SE})$, longest in H. crudiae ( $41.0 \pm 0.0$ days) and intermediate in the other three Hypothenemus spp. (Table 1), which generally agrees with the phylogenetic pattern observed for parasitism and emergence (Fig. 1). The percentage of female versus male $P$. coffea emerging from parasitized $H$. hampei was $50.8 \% \pm 0.4$ (mean $\pm \mathrm{SE}$ ), which was significantly different $\left(\chi^{2}=27.3\right.$, $\mathrm{df}=4, p=0.0001)$ from $H$. seriatus and H. birmanus (Table 1). Hypothenemus eruditus was not parasitized by $P$. coffe $a$ and hence was not included in any statistical analyses.

Parasitized $H$. hampei had the lowest percentage of unemerged parasitoids compared to the other four Hypothenemus species (Fig. 1), indicating that H hampei is a superior host for $P$. coffea development. For each parasitized host beetle with unemerged parasitoids, invariably two parasitoids were present, and the parasitoids were of the same life stage (larva, pupa or adult). The frequency of the different life stages for parasitized hosts with unemerged parasitoids differed among Hypothenemus species (Fig. 2). Parasitized $H$. hampei had a significantly lower percentage of larval $\left(\chi^{2}=15.10, \mathrm{df}=3, p=0.001\right)$, and higher percentage of adult parasitoids that were unemerged $\left(\chi^{2}=18.36, \mathrm{df}=3\right.$, $p=0.0001)$ compared to the other Hypothenemus species. The higher percentage of unemerged parasitoids developing to the adult stage again indicates that $H$. hampei is a superior developmental host than the other Hypothenemus spp. The percentage of unemerged pupae found in parasitized $H$. hampei was not significantly different from $H$. obscurus, $H$. seriatus and $H$. birmanus, but $H$. crudiae had a significantly higher percentage of pupae than $H$. hampei

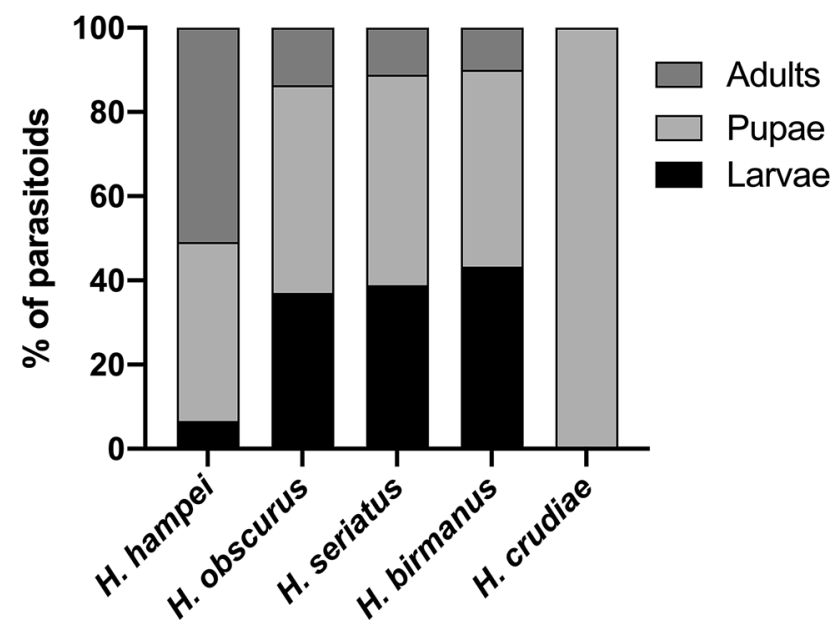

Fig. 2 Fate of unemerged Phymastichus coffea parasitoids from parasitized Hypothenemus spp. in no-choice in vitro non-target host selection screening. Parasitized Hypothenemus beetles with unemerged parasitoids were dissected to identify life stages (larva, pupa, adult)

$\left(\chi^{2}=95.40, \mathrm{df}=4, p=0.0001\right)$ (Fig. 2). No eggs were found in any of the parasitized Hypothenemus hosts.

\section{Discussion}

Phymastichus coffea is a potential biological control agent of H. hampei and was brought from Columbia into a quarantine containment facility in Hawaii for host range testing to determine whether the parasitoid might attack non-target species and therefore pose a risk to Hawaiian endemic species. Using no-choice tests, 43 different species of Coleoptera were exposed to $P$. coffea in vitro, including 23 scolytines (six natives, 17 non-native species including $H$. hampei), six beneficial species and 12 other species including one native weevil ( $N$. giffardi). Only five species from the genus Hypothenemus were parasitized by $P$. coffea, including the two pest species $H$. hampei (coffee berry borer) and $H$. obscurus (tropical nut borer, a macadamia nut pest), and three other exotic species $H$. seriatus, $H$. birmanus and $H$. crudiae (Fig. 1). Thus, P. coffea appears to be host specific at the genus level and should pose no harm to endemic species if released in Hawaii coffee for classical biological control of $H$. hampei. Nevertheless, no level of host specificity testing can ensure zero risk to non-target organisms when introducing a natural enemy in a new habitat (Louda et al. 2003).

We observed that once the host and parasitoids were exposed in the Petri dish arena that $P$. coffea inspected $H$. hampei and other Hypothenemus spp. hosts by antennation before proceeding to oviposition or rejection. Phymastichus coffea did not show any oviposition response to other nontarget hosts. This could be dependent on several factors 
because parasitoids may search and decide host suitability by using a broad spectrum of different stimuli such as plant-host complex volatiles, host feces volatiles, host sex pheromones, and tactile and visual cues (Chiu-Alvarado and Rojas 2008; Yang et al. 2008). Host habitat and host diet may influence the volatile composition emitted by the potential host insect, which can either deter or attract parasitoids from a distance. To minimize the effect of diet, we provided a general beetle diet to all the field-collected coleopteran hosts during the experiments. Parasitism of non-target hosts in the field may not be the same as our in vitro test results because of various factors related to the host's natural habitat. Most of the coleopteran species tested in our study are normally found tunneling in seeds, decomposing wood (under the bark and/or in sapwood) or decaying fruits. This cryptic behavior would likely provide protection from $P$. coffea which is accustomed to searching for $H$. hampei adult females, while they are exposed on the surface of coffee berries.

Phymastichus coffea was attracted to and parasitized only four species of Hypothenemus in addition to its target host $H$. hampei. This is consistent with studies reported by LópezVaamonde and Moore (1998), and Castillo et al. (2004). Combining information from our study and previous studies, seven species of beetles are now known to be able to serve as hosts in captive exposure studies for $P$. coffea: $\mathrm{H}$. hampei, H. obscurus, H. seriatus, Araptus sp. (Lopez-Vaamonde and Moore 1998), H. crudiae and H. eruditus (Castillo et al. 2004), in addition to H. birmanus (this study). Parasitism of the scolytine Araptus sp. seems to be an outlier, but this genus does not occur in Hawaii. Aside from Araptus, P. coffea appears to be genus specific attacking closely related, but not all Hypothenemus species, given that species from closely related genera were not parasitized under no-choice test conditions. In our study, $P$. coffea did not attack $H$. eruditus. We believe that $H$. eruditus may not be a suitable host for the parasitoid because of its small size $(\leq 1 \mathrm{~mm})$; Phymastichus coffea usually lays two eggs per host (1 male and 1 female), and in such a small host, successful development would be unlikely due to the limited availability of resources within the host. Host size is an important variable on which the survival and growth of parasitoid progeny depends. Females of most parasitoids preferentially lay eggs on larger hosts (Fox and Mousseau 1995). Also, H. eruditus is phylogenetically distant from H. hampei (Fig. 1) which is addressed below.

Our results also showed that $H$. hampei had the lowest numbers of unemerged parasitoids when compared with the other four Hypothenemus species (Fig. 2). The number of larvae and pupae were lower, and adults were higher in parasitized $H$. hampei with unemerged parasitoids. Similarly, in other three Hypothenemus spp. (H. obscurus, H. seriatus and $H$. birmanus) many unemerged parasitoids could not complete their development and died in their larval or pupal stage with only a few reaching to the adult stage. In parasitized $H$. crudiae with unemerged parasitoids, most apparently could not reach the adult stage. Although the rate of completing the life cycle differed among Hypothenemus species, eggs did hatch in all parasitized species. Many factors can be responsible for suitability of the host for parasitoid development (Pennacchio and Strand 2006). Factors such as host physiology (e.g., presence of endosymbiotic bacteria), behavior (e.g., feeding habitat-sequestering secondary metabolites) and ecology (e.g., spatial/temporal overlap) may influence host acceptance by parasitoids and successful development (Desneux et al. 2009). All the non-target species used in the experiments were freshly collected from the field and may have carried toxins (accumulated from plant feeding) that may have interfered with the successful development of immature parasitoids within the hosts due to the ingestion of unsuitable food (e.g., see Desneux et al. 2009).

Phymastichus coffea also did not successfully parasitize any of the non-Hypothenemus species tested, including both native (Xyleborus) and exotic (Xyleborinus, Xylosandrus, Xyloborus, Euwallacea, others) Scolytinae, and other curculionid species from subfamilies other than Scolytinae, including the native weevil, $N$. giffardi. We did not find any $P$. coffea life stages (eggs, larvae, pupae, adults) after dissection in any of the non-Hypothenemus non-target species tested (Tables 2, 3, 4). Host specialization is relatively common in parasitic Hymenoptera and can be related to phylogeny, ecology and life histories (Price 1980; Stireman et al. 2006). It appears that at least host phylogeny was an important factor in host selection for $P$. coffea under our laboratory conditions.

Host range of idiobiont parasitoids is typically broader than koinobiont species (Askew and Shaw 1986; Hawkins et al. 1992), and it would hypothetically be reasonable to expect that $P$. coffea would follow this pattern. However, our results show that $P$. coffea was unable to successfully parasitize any species outside of the genus Hypothenemus and, even within the genus, was only moderately successful on species even closely related to $H$. hampei. While parasitism of $H$. hampei and subsequent parasitoid emergence was relatively high, both were significantly lower in $H$. obscurus and $H$. seriatus, sister species to $H$. hampei; $H$. eruditus, in a sister clade to the other species (Johnson et al. 2018), had zero parasitism. This demonstrates decreasing susceptibility to $P$. coffea with increasing phylogenetic distance among the Hypothenemus spp. exposed to the parasitoids in this study. Among the Hypothenemus spp. included in the phylogenetic reconstruction published by Johnson et al. (2018), H. hampei is the only species that has undergone a reversal in host range breadth, to become monophagous on coffee, while the other Hypothenemus spp. have retained a host generalist biology. Hypothenemus hampei has developed a unique association with Pseudomonas bacterial endosymbionts to 
facilitate detoxification of caffeine, permitting it to exploit Coffea arabica seeds as their host (Ceja-Navarro et al. 2015), and potentially other physiological adaptations to its unique host, possibly providing adaptive challenges to parasitoids, and mediating host specificity of $P$. coffea. Messing (2001) questioned the practicality of applying centrifugal phylogeny approaches to selecting species to examine in non-target studies of potential biological control agents, particularly parasitoids. Our results support the predictions of the latter approach, with more distantly related Hypothenemus species less susceptible to $P$. coffea attack and more distantly related genera (e.g., Xyleborus spp.) not attacked at all. However, Messing (2001) emphasized the fact that interactions between the host insect and its host plant may override host phylogenetic patterns, by providing the stimuli for parasitoids to attack hosts, a consideration which may play a role in this study system. If this is the case, it is possible that $P$. coffea will produce even higher levels of parasitism than recorded in the artificial environment we used in our study, when attacking wild $H$. hampei boring into coffee fruits, producing the full range of cues stimulating parasitism, and lower field parasitism of the non-target Hypothenemus spp. included here.

Among all the parasitized Hypothenemus species, $H$. hampei had the highest rate of parasitoid emergence. The total developmental time (from egg to adult) of $P$. coffea was shortest in $H$. hampei (32 days); parasitism of $\mathrm{H}$. crudiae resulted in the longest developmental time (41 days). Another study reported a similar development time of the P. coffea in H. hampei, $38-42$ days at $23{ }^{\circ} \mathrm{C}$ and $66 \% \mathrm{RH}$ (Rafael et al. 2000). Castillo et al. (2004) reported a P. coffea development time of 42.6 days for $H$. hampe $i$ and 40 days for $H$. crudiae at $26 \pm 2{ }^{\circ} \mathrm{C}$ and $70-80 \%$ RH. Total developmental time is directly related to the temperature. For example, the total development period of Diglyphus isaea (Hymenoptera:Eulophidae) decreased with increasing temperature between 15 and $35^{\circ} \mathrm{C}$ and no development was found at 10 and $40{ }^{\circ} \mathrm{C}$ (Haghani et al. 2007). Temperature is a critical abiotic factor influencing the physiology and dynamics of insects. Therefore, in this study we selected a temperature for our no-choice assays which reflects the ambient field temperature the insects are expected to experience. In addition to temperature, age of the parasitoids and host play an important role in the subsequent development of parasitoid offspring (Pizzol et al. 2012). Hence, we used uniformly aged parasitoids and hosts throughout our experiments to minimize any impact on host parasitism and parasitoid development.

Phymastichus coffea commonly lays two eggs (a male and a female) per host (López-Vaamonde and Moore 1998). Both male and female develop in a single host, the female in the abdomen and the male in the prothorax (Espinoza et al. 2009). In this study, slightly fewer male parasitoids emerged as compared to females from parasitized hosts. The proportion of females emerging from $H$. hampei was $50.8 \%$ which is consistent with the results obtained by López-Vaamonde and Moore (1998) and Rafael et al. (2000). Likewise, sex ratios of P. coffea emerging from $H$. obscurus $54.8 \%$, $H$. seriatus $51.1 \%$ and $H$. crudiae $50.0 \%$ were consistent with the sex ratio results reported by (López-Vaamonde and Moore 1998; Castillo et al. 2004) of 1.25:1, 1:1 and 1:1 (female-male), respectively, for these species. In our study, the proportion of females emerging from parasitized H. birmanus $57.7 \%$, was the highest among all other Hypothenemus species tested. The slightly fewer males produced per host in our study could be due to either to some parasitoid's preference to lay one egg per host (Feldhege 1992) or the lower survivorship of male eggs or larvae. Preference to lay female eggs over male can be dependent on several factors such as host quality, host age, immune response, genetic factors, photoperiod and relative humidity, host density or host-related volatile composition (King 1987).

All the above tests were conducted in a quarantine laboratory with no field studies. We conducted no-choice tests because they may provide more accurate and conservative information on host preferences and physiological host range than choice tests because of lower levels of interference due to unexpected responses to multiple host cues (Van Driesche and Murray 2004). Sands (1997) showed that laboratory studies often overestimate the host range of the parasitoid and realized ranges under field conditions may be substantially less than predicted from no-choice tests, but they are necessary to give a worst-case prediction of the number of hosts at risk of being attacked in the field (Avilla et al. 2016). Phymastichus coffea attacked other non-target Hypothenemus species in our no-choice trials, but this does not necessarily mean that those species will be attacked in the field. For example, an idiobiont braconid wasp, Bracon hebetor is reported to parasitize a wide variety of moths within and outside in Phycitinae (Lepidoptera:Noctuidae) in the laboratory, but in the field it is restricted to only larvae of Plodia interpunctella (Lepidoptera:Noctuidae) (Antolin et al. 1995). This is because in the field, parasitoids use a spectrum of long- and short-range cues (chemical, visual, vibrational and tactile signals) to locate hosts (Strand and Pech 1995). Chemical cues (infochemicals) can play an important role in host location. A study conducted by Rojas et al. (2006) showed that $P$. coffea can distinguish between $H$. hampei-infested and uninfested coffee berries, and were highly attracted to the dust/frass originating from $\mathrm{H}$. hampei infested berries, but showed no response to the dust/ frass originated from the closely related non-target host, $H$. crudiae. This behavior depending on plant and host cues suggests that it is very unlikely that $P$. coffea will have any 
negative effects on non-target scolytids, or any other beetles, under field conditions.

No biocontrol agents were previously released in Hawaii against $H$. hampei. Two exotic predatory beetles, Cathartus quadricollis and Leptophloeus sp., are commonly found in overripe and dried coffee berries predating on the immature stages of H. hampei (Follett et al. 2016; Brill et al. 2020). Our host testing in quarantine showed that $P$. coffea will not parasitize these beetles and that the beetles did not predate on the parasitoids. Also, these predators attack eggs, larvae and pupae of $H$. hampei in overripe and dried berries (left after harvesting), whereas $P$. coffe $a$ only attacks adult female $H$. hampei at an earlier stage of crop maturity. The other four Hypothenemus species that were attacked by $P$. coffea have very different field habitats, but might serve as useful transitory hosts for $P$. coffea at times when, or in areas where, $H$. hampei populations are at low densities, such as between coffee seasons. For example, macadamia nut farms are often located close to coffee farms in Hawaii and may provide a year-round source of $H$. obscurus, a pest of macadamia nut. Feral coffee in Hawaii could also serve as a continuous source of $H$. hampei throughout the year.

Phymastichus coffea is a potentially effective biological control agent for $H$. hampei and could be incorporated into existing IPM programs in Hawaii. Phymastichus coffea may be simply released and monitored for establishment in a classical biological control program, or it may be mass reared for inundative releases. Currently, trapping and sampling of infested coffee fruits is conducted to monitor H. hampei flights and optimize timing of Beauveria bassiana applications for control (Aristizabal et al. 2016). After H. hampei bores into the coffee berries, it is protected and difficult to control with biopesticides or conventional insecticides. To achieve maximum $P$. coffea parasitism in the field, inundative releases should be made at times when $H$. hampei adults are active (e.g., when trap catches are high or female $H$. hampei are actively boring into fruits) and the coffee crop is at a susceptible stage. Optimal timing of inundative releases may differ for different elevations due to $H$. hampei population dynamics (Hamilton et al. 2019). Studies suggest $P$. coffea may be susceptible to B. bassiana, however (Barrera 2005; Castillo et al. 2009; Ruiz et al. 2011), so inundative releases should be timed to avoid $B$. bassiana applications or used in alternation with $B$. bassiana against $H$. hampei. If $P$. coffea is highly effective, then dependence on $B$. beauveria applications could be reduced dramatically.

\section{Author contributions}

FY designed methodology, conducted the experiments and wrote the manuscript; PF designed the experiments; $\mathrm{PF}$ and MW provided overall project management and manuscript editing; FY, CG and DH conducted field surveys and collected live beetles for testing. FY, CG and LC identified beetle species; MGJ and PBM reared and supplied Phymastichus coffea. All authors read and gave final approval for publication.

Acknowledgements We gratefully thank Cynthia King (Division of Forestry and Wildlife, Hawaii Department of Land and Natural Resources), Tabetha Block (Hawaii Experimental Tropical Forest, USDA Forest Service) and Rhonda Loh (US National Park Service) for their assistance in obtaining research permits. We would like to also thank Jared Bernard (University of Hawaii at Manoa) for his help in confirming specimen identifications, Lindsey Hamilton, Shinyoung Park and Glenn Asmus at the USDA-ARS (Hilo, Hawaii) facility for fieldwork assistance and $H$. hampei extraction from coffee berries. This study was supported through a cooperative agreement with USDAAPHIS, awards \# AP18PPQS and T00C158, and the Hawaii Department of Agriculture. This article reports the results of research only. Mention of a proprietary product does not constitute an endorsement or a recommendation by the USDA for its use. USDA is an equal opportunity employer.

Funding This study was supported through a cooperative agreement with USDA-APHIS, award \# AP18PPQSand T00C158.

\section{Declarations}

Conflict of interest The authors have declared that no conflict of interest exists.

Informed consent Informed consent was obtained from all individual participants included in the study.

Open Access This article is licensed under a Creative Commons Attribution 4.0 International License, which permits use, sharing, adaptation, distribution and reproduction in any medium or format, as long as you give appropriate credit to the original author(s) and the source, provide a link to the Creative Commons licence, and indicate if changes were made. The images or other third party material in this article are included in the article's Creative Commons licence, unless indicated otherwise in a credit line to the material. If material is not included in the article's Creative Commons licence and your intended use is not permitted by statutory regulation or exceeds the permitted use, you will need to obtain permission directly from the copyright holder. To view a copy of this licence, visit http://creativecommons.org/licenses/by/4.0/.

\section{References}

Antolin MF, Ode PJ, Strand MR (1995) Variable sex ratios and ovicide in an outbreeding parasitic wasp. Anim Behav 49:589-600. https://doi.org/10.1016/0003-3472(95)80192-8

Aristizábal LF, Bustillo AE, Arthurs SP (2016) Integrated pest management of coffee berry borer:strategies from Latin America that could be useful for coffee farmers in Hawaii. Insects 7:6. https:// doi.org/10.3390/insects7010006

Askew RR, Shaw MR (1986) Parasitoid communities:their size structure and development. In: Waage J, Greathead D (eds) Insect parasitoids. Academic Press, London, pp 225-264. https://doi.org/10. 1007/BF00317230 
Avila GA, Withers TM, Holwell GI (2016) Retrospective risk assessment reveals likelihood of potential non-target attack and parasitism by Cotesia urabae (Hymenoptera:Braconidae): a comparison between laboratory and field-cage testing results. Biol Cont 103:108-118. https://doi.org/10.1016/j.biocontrol.2016.08.008

Baker PS (1999) The coffee berry borer in Colombia:Final report of the DFID-Cenicafé-CABI Bioscience IPM for coffee project (CNTR 93/1536A). DFID-CENICAFÉ.

Barrera JF Investigación sobre la broca del café en México:logros, retos y perspectivas (2005) In: Simposio sobre Situación Actual y Perspectivas de la Investigación y Manejo de la Broca del Café en Costa Rica, Cuba, Guatemala y México. Sociedad Mexicana de Entomología y El Colegio de la Frontera Sur. Tapachula, Chiapas, México, pp 1-13

Barrera JF, Baker PS, Valenzuela JE, Schwarz A (1990) Introducción de dos especies de parasitoides africanos a México para el control biológico de la broca del café, Hypothenemus hampei (Ferrari)(Coleoptera:Scolytidae). Folia Entomológica Mexicana 79:245-247

Brill E, Follett PA, Kawabata AM (2020) Feeding habits, movement, and reproduction of the predatory flat bark beetles Cathartus quadricollis (Coleoptera:Silvanidae) and Leptophloeus sp. (Coleoptera:Laemophloeidae) in Hawaii coffee and macadamia nut. Int J Trop Insect Sci 2020:1-10. https://doi.org/10.1007/ s42690-020-00205-9

Brun L-O, Gaudichon V, Wigley P (1993) An artificial diet for continuous rearing of the coffee berry borer, Hypothenemus hampei (Ferrari) (Coleoptera:Scolytidae). Int J Trop Insect Sci 14:585587. https://doi.org/10.1017/S1742758400017963

Burbano E, Wright M, Bright DE, Vega FE (2011) New record for the coffee berry borer, Hypothenemus hampei, in Hawaii. J Insect Sci 11:1-3. https://doi.org/10.1673/031.011.11701

Bustillo AE, Cárdenas R, Villalba D, Benavides P, Orozco J, Posada F, Manejo Integrado de la Broca Del Café, Hypothenemus hampei (Ferrari) en Colombia, 1st ed. Cenicafé: Chinchiná, Colombia, 1998; p 134

Castillo A, Gómez J, Infante F, Vega FE (2009) Susceptibilidad del parasitoide Phymastichus coffea LaSalle (Hymenoptera:Eulophidae) a Beauveria bassiana en condiciones de laboratorio. Neotrop Entomol 38:665-670. https:// doi.org/10.1590/S1519-566X2009000500017

Castillo A, Infante F, López G, Trujillo J, Kirkendall LR, Vega FE (2004) Laboratory parasitism by Phymastichus coffea (Hymenoptera:Eulophidae) upon non-target bark beetles associated with coffee plantations. Fla Entomol 87:274-277. https:// doi.org/10.1653/0015-4040(2004)087[0274:LPBPCH]2.0

Ceja-Navarro JA, Vega FE, Karaoz U, Hao Z, Jenkins S, Lim HC, Kosina P, Infante F, Northen TR, Brodie EL (2015) Gut microbiota mediate caffeine detoxification in the primary pest of coffee. Nat Commun 6:7618. https://doi.org/10.1038/ncomms8618

Chiu-Alvarado P, Rojas JC (2008) Host location behaviour by two Cephalonomia spp (Hymenoptera:Bethylidae) wasps associated with the coffee berry borer Hypothenemus hampei (Coleoptera: Curculionidae:Scolytinae). Int J Trop Insect Sci 28(4):179-184. https://doi.org/10.1017/S1742758408199660

Cognato AI, Rubinoff D (2008) New exotic ambrosia beetles found in Hawaii (Curculionidae:Scolytinae:Xyleborina). Coleopts Bull 62:421-424. https://doi.org/10.1649/1084.1

Damon A (2000) A review of the biology and control of the coffee berry borer, Hypothenemus hampei (Coleoptera:Scolytidae). Bull Entomol Res 90:453-465. https://doi.org/10.1017/S0007 485300000584

Decazy B (1990) Descripción, biología, ecología y control de la broca del fruto del cafeto, Hypothenemus hampei (Ferr.). Paper presented at the 50 años de Cenicafé 1938-1988, Conferencias Conmemorativas, Chinchiná, Colombia.
Desneux N, Barta RJ, Hoelmer KA, Hopper KR, Heimpel GE (2009) Multifaceted determinants of host specificity in an aphid parasitoid. Oecologia 160:387-398. https://doi.org/10.1007/ s00442-009-1289-x

Escobar-Ramírez S, Grass I, Armbrecht I, Tscharntke T (2019) Biological control of the coffee berry borer:main natural enemies, control success, and landscape influence. Biol Cont 136:103992. https://doi.org/10.1016/j.biocontrol.2019.05.011

Espinoza JC, Infante F, Castillo A, Pérez J, Nieto G, Pinson EP, Vega FE (2009) The biology of Phymastichus coffea LaSalle (Hymenoptera:Eulophidae) under field conditions. Biol Cont 49:227-233. https://doi.org/10.1016/j.biocontrol.2009.01.021

Feldhege M (1992) Rearing techniques and aspects of biology of Phymastichus coffea (Hymenoptera:Eulophidae), a recently described endoparasitoid of the coffee berry borer, Hypothenemus hampei (Coleoptera:Scolytidae) Café. Cacao 36:45-54

Follett PA, Duan J (1999) Nontarget effects of biological control. Kluwer Academic Publishers, Boston, p 316. https://doi.org/ 10.1007/978-1-4615-4577-4

Follett PA et al (2016) Predation by flat bark beetles (Coleoptera: Silvanidae and Laemophloeidae) on coffee berry borer (Coleoptera:Curculionidae) in Hawaii coffee. Biol Cont 101:152-158. https://doi.org/10.1016/j.biocontrol.2016.07.002

Fox CW, Mousseau TA (1995) Determinants of clutch size and seed preference in a seed beetle, Stator beali (Coleoptera:Bruchidae). Environ Entomol 24:1557-1561. https://doi.org/10.1093/ee/ 24.6.1557

Gillett CPDT, Honsberger D, Elliott C, Rubinoff D (2020a) Two endemic species of Hawaiian bark beetles newly recorded from the island of Moloka'i (Coleoptera:Curculionidae:Scolytinae). Trans Am Entomol Soc 146:251-257. https://doi.org/10.3157/ 061.146.0108

Gillett CPDT, Yousuf F, Rubinoff D (2020b) First host plant record for the endemic Hawaiian ambrosia beetle Xyleborus pleiades Samuelson, 1981 (Coleoptera:Curculionidae:Scolytinae). P Hawaii Entomol Soc 52:5-7. http://hdl.handle.net/10125/67801

Gillett CP, Elliott C, Rubinoff D (2019) Records of seven species of native and exotic bark beetles new to Pu'u Wa' awa' a Dry Forest Unit, Hawai 'i Island (Coleoptera:Curculionidae, Scolytinae). Fragmenta Entomologica 51:233-240. https://doi.org/10.4081/ fe.2019.381

Gutierrez AP, Villacorta A, Cure JR, Ellis CK (1998) Tritrophic analysis of the coffee (Coffea arabica)-coffee berry borer [Hypothenemus hampei (Ferrari)]-parasitoid system. Anais da Sociedade Entomologica do Brasil 27:357-385. https://doi.org/ 10.1590/S0301-80591998000300005

Haghani M, Fathipour Y, Talebi AA, Baniameri V (2007) Temperature-dependent development of Diglyphus isaea (Hymenoptera:Eulophidae) on Liriomyza sativae (Diptera:Agromyzidae) on cucumber. J Pest Sci 80:71-77. https://doi.org/10.1007/s10340-006-0154-5

Hamilton LJ, Hollingsworth RG, Sabado-Halpern M, Manoukis NC, Follett PA, Johnson MA (2019) Coffee berry borer (Hypothenemus hampei) (Coleoptera:Curculionidae) development across a elevational gradient on Hawai'i Island: applying laboratory degree-day predictions to natural field populations. PLoS ONE. https://doi.org/10.1371/journal.pone.0218321

Hawkins BA, Shaw MR, Askew RR (1992) Relations among assemblage size, host specialization and climate variability in North American parasitoid communities. Am Nat 139:58-79. https:// doi.org/10.1086/285313

Henneman ML, Memmott J (2001) Infiltration of a Hawaiian community by introduced biological control agents. Science 293(5533):1314-1316. https://doi.org/10.1126/science.1060788 
Howarth FG (1991) Environmental impacts of classical biological control. Ann Rev Entomol 36:485-509. https://doi.org/10.1146/ annurev.en.36.010191.002413

Infante F (2018) Pest management strategies against the coffee berry borer (Coleoptera:Curculionidae:Scolytinae). J Agric Food Chem 66:5275-5280. https://doi.org/10.1021/acs.jafc.7b04875

Infante F, Castillo A, Pérez J, Vega FE (2013) Field-cage evaluation of the parasitoid Phymastichus coffea as a natural enemy of the coffee berry borer, Hypothenemus hampei. Biol Contl 67:446-450. https://doi.org/10.1016/j.biocontrol.2013.09.019

Infante F, Murphy ST, Barrera Gaytán J, Gómez J, Damon A (1994) Cría de Phymastichus coffea parasitoide de la broca del café y algunas notas sobre su historia de vida. Southwest Entomol 19:313-315. https://doi.org/10.1079/BER2005378

Jaramillo J, Bustillo A, Montoya E, Borgemeister C (2005) Biological control of the coffee berry borer Hypothenemus hampei (Coleoptera:Curculionidae) by Phymastichus coffea (Hymenoptera:Eulophidae) in Colombia. B Entomol Res 95:467-472. https://doi.org/10.1079/BER2005378

Jaramillo J, Borgemeister C, Baker P (2006) Coffee berry borer Hypothenemus hampei (Coleoptera:Curculionidae): searching for sustainable control strategies. B Entomol Res 96:223-233. https://doi.org/10.1079/ber2006434

Johnson MT, Follett PA, Taylor AD, Jones VP (2005) Impacts of biological control and invasive species on a non-target native Hawaiian insect. Oecologia 142:529-540. https://doi.org/10.1007/ s00442-004-1754-5

Johnson AJ, McKenna DD, Jordal BH, Cognato AI, Smith SM, Lemmon AR, Lemmon EM, Hulcr J (2018) Phylogenomics clarifies repeated evolutionary origins of inbreeding and fungus farming in bark beetles (Curculionidae, Scolytinae). Mol Phylogenetics Evol 127:229. https://doi.org/10.1016/j.ympev.2018.05.028

Johnson MA, Ruiz-Diaz CP, Manoukis NC, Verle Rodriques JC (2020) Coffee berry borer (Hypothenemus hampei), a global pest of coffee: Perspectives from historical and recent invasions, and future prioroties. Insects 11:882. https://doi.org/10.3390/insects111 20882

Kaufman LV, Wright MG (2009) The impact of exotic parasitoids on populations of a native Hawaiian moth assessed using life table studies. Oecologia 159:295-304. https://doi.org/10.1007/ s00442-008-1226-4

Kaufman LV, Wright MG (2011) Ecological correlates of the nonindigenous parasitoid assemblage associated with a Hawaiian endemic moth. Oecologia 166:1087-1098. https://doi.org/10. 1007/s00442-011-1949-5

King BH (1987) Offspring sex ratios in parasitoid wasps. Q Rev Biol 62:3396. https://doi.org/10.1086/415618

Klein-Koch C, Espinoza O, Tandazo A, Cisneros P, Delgado D (1988) Factores naturales de regulación y control biológico de la broca del café (Hypothenemus hampei Ferr). Sanidad Vegetal 3:5-30

LaSalle J (1990) A new genus and species of Tetrastichinae (Hymenoptera:Eulophidae) parasitic of the coffee berry borer, Hypoythenemus hampei (Ferrari) (Coleoptera:Scolytidae). Bull Entomol Res 80:7-10. https://doi.org/10.1017/S00074853000458 43

López-Vaamonde C, Moore D (1998) Developing methods for testing host specificity of Phymastichus coffea LaSalle (Hym.:Tetrastichinae), a potential biological control agent of Hypothenemus hampei (Ferrari)(Col.:Scolytidae) in Colombia. Biocontrol Sci Techn 8:397-411. https://doi.org/10.1080/09583 159830207

Louda SM, Pemberton RW, Johnson MT, Follett PA (2003) Nontarget effects-the Achilles' heel of biological control? Retrospective analyses to reduce the risk of biocontrol introductions. Ann Rev Entomol 48:365-396. https://doi.org/10.1146/annurev.ento.48. 060402.102800
Messing RH (2001) Centrifugal phylogeny as a basis for non-target host testing in biological control:is it relevant for parasitoids? Phytoparasitica 29:187-190. https://doi.org/10.1007/BF02983449

Messing RH, Wright MG (2006) Biological control of invasive species: solution or pollution? Front Ecol Environ 4:132-140. https://doi. org/10.1890/1540-9295(2006)004[0132:BCOISS]2.0.CO;2

Nishida GM (2002) Hawaiian terrestrial arthropod checklist, 4th ed. Bishop Museum Technical Report No. 22, Honolulu, Hawaii, USA

Orozco J, Aristizábal LF (1996) Parasitoides de origen africano para el control de la broca del café. Centro Nacional de Investigaciones de Café (Cenicafé)

Pizzol J, Desneux N, Wajnberg E, Thiéry D (2012) Parasitoid and host egg ages have independent impact on various biological traits in a Trichogramma species. J Pest Sci 85:489-496. https://doi.org/ 10.1007/s10340-012-0434-1

Pennacchio F, Strand MR (2006) Evolution of developmental strategies in parasitic hymenoptera. Annu Rev Entomol 51:233-258. https:// doi.org/10.1146/annurev.ento.51.110104.151029

Portilla M, Grodowitz M (2018) A novel method to evaluate the reproductive potential of Phymastichus coffea (Hymenoptera:Eulophidae) in Hypothenemus hampei (Coleopter a:Curculionidae:Scolytinae) under laboratory conditions. J Insect Sci 18:15. https://doi.org/10.1093/jisesa/iey123

Price PW (1980) Evolutionary biology of parasites. Princeton University Monograph, Princeton

Rafael T, Paz H, Muñoz R (2000) Advances in the biological control of the coffee berry borer Hypothemus hampei Ferr. using the parasitoid Phymastichus coffea. In: 19th Simposio Latinoamericano de caficultura. Memoria, San José, Costa Rica, 2-6 Octubre 2000., Instituto del Café de Costa Rica, ICAFE, pp 321-329

Razali NM, Wah YB (2011) Power comparisons of Shapiro-Wilk, Kolmogorov-Smirnov, Lilliefors and Anderson-Darling tests. J Stat Mod An 2:21-33

Rodríguez D, Cure JR, Gutierrez AP, Cotes JM (2017) A coffee agroecosystem model: III. Parasitoids of the coffee berry borer (Hypothenemus hampei). Ecol Model 363:96-110. https://doi.org/ 10.1016/j.ecolmodel.2017.08.008

Rojas JC, Castillo A, Virgen A (2006) Chemical cues used in host location by Phymastichus coffea, a parasitoid of coffee berry borer adults, Hypothenemus hampei. Biol Control 37(2):141-147

Ruiz JG, Ovilla AS, Valle-Mora J, Gerardo PJM (2011) Determinación del establecimiento de parasitoides de la broca del café Hypothenemus hampei (Coleoptera:Curculionidae, Scolytinae) en cafetales del Soconusco, Chiapas, México. Entomotropica 25:25-35

Samuelson G (1981) A synopsis of Hawaiian Xyleborini (Coleoptera:Scolytidae). Pac Insects 23:50-92

Sands D (1997) The "safety" of biological control agents: assessing their impact on beneficial and other non-target hosts. Memoirs of Museum Victoria 56:611-615. https://doi.org/10.24199/j.mmv. 1997.56.58

Shapiro SS, Wilk MB (1965) An analysis of variance test for normality (complete samples). Biometrika 52:591-611. https://doi.org/10. 1093/biomet/52.3-4.591

Stireman JO, Nason JD, Heard SB, Seehawer JM (2006) Cascading host-associated genetic differentiation in parasitoids of phytophagous insects. Proc R Soc Lond B Biol 273:523-530. https://doi. org/10.1098/rspb.2005.3363

Strand MR, Pech LL (1995) Immunological basis for compatibility in parasitoid-host relationships. Annu Rev Entomol 40:31-56. https://doi.org/10.1146/annurev.en.40.010195.000335

Swezey OH (1954) Forest Entomology in Hawaii. An annotated checklist of the insect faunas of the various components of the Hawaiian forests. Bernice P, Bishop Museum, Honolulu, Hawaii

USDA National Agricultural Statistics Service (NASS), in cooperation with the Hawaii department of agriculture. Pacific Region: Hawaii 
coffee marketings final season estimates (2018) https://www.nass. usda.gov/Statistics_by_State/Hawaii/Publications/Fruits_and_ Nuts/201807FinalCoffee.pdf. Accessed 14 August 2020

Van Driesche RG, Murray TJ (2004) Overview of testing schemes and designs used to estimate host ranges, pp. 56-67, In: Van Driesche RG, Reardon R (eds), Assessing host ranges for parasitoids and predators used for classical biological control: a guide to best practice. United States Department of Agriculture Forest Health Technology Enterprise Team, Morgantown, West Virginia, USA FHTET-2004-03. https://www.fs.fed.us/foresthealth/technology/ pdfs/HostRangeBook.pdf

Vega FE, Infante F, Johnson AJ (2015) The genus Hypothenemus, with emphasis on H. hampei, the coffee berry borer. In: Vega FE, Hfstetter R (eds) Bark beetles. Academic Press, Elsevier, pp 427-494. https://doi.org/10.1016/b978-0-12-417156-5.00011-3
Vergara JD, Orozco J, Bustillo A, Chavez B (2001) Dispersion de Phymasticus coffea en un lote de café infestado de Hypothenemus hampei. Rev Cenicafe 52:104-110

Withers TM, Mansfield S (2005) Choice or no-choice tests? Effects of experimental design on the expression of host range, pp. 620-633 In: Hoddle MS (ed), Proceedings 2nd international symposium of biological control of arthropods, 12-16 September 2005, Davos, Switzerland. USDA, Forest health technology enterprise team, Morgantown, West Virginia, USA

Yang Z-Q, Wang X-Y, Gould JR, Wu H (2008) Host specificity of Spathius agrili Yang (Hymenoptera:Braconidae), an important parasitoid of the emerald ash borer. Biol Cont 47:216-221. https:// doi.org/10.1016/j.biocontrol.2008.08.001

Publisher's Note Springer Nature remains neutral with regard to jurisdictional claims in published maps and institutional affiliations. 